\title{
The MoHole: A Crustal Journey and Mantle Quest, Workshop in Kanazawa, Japan, 3-5 June 2010
}

\author{
by Benoît Ildefonse, Natsue Abe, Donna K. Blackman, J. Pablo Canales, Yoshio \\ Isozaki, Shuichi Kodaira, Greg Myers, Kentaro Nakamura, Mladen Nedimovic, \\ Alexander C. Skinner, Nobukazu Seama, Eiichi Takazawa, Damon A.H. Teagle, \\ Masako Tominaga, Susumu Umino, Douglas S. Wilson, and Masaoki Yamao
}

doi: 10.2204/iodp.sd.10.07.2010

\section{Introduction}

Drilling an ultra-deep hole in an intact portion of oceanic lithosphere, through the crust to the Mohorovičić discontinuity (the 'Moho'), and into the uppermost mantle is a long-standing ambition of scientific ocean drilling (Bascom, 1961; Shor, 1985; Ildefonse et al., 2007). It remains essential to answer fundamental questions about the dynamics of the Earth and global elemental cycles. The global system of mid-ocean ridges and the new oceanic lithosphere formed at these spreading centers are the principal pathways for energy and mass exchange between the Earth's interior, hydrosphere, and biosphere. Bio-geochemical reactions between the oceans and oceanic crust continue from ridge to subduction zone, and the physical and chemical changes to the ocean lithosphere provide inventories of these thermal, chemical, and biological exchanges.

The 2010 MoHole workshop in Kanazawa, Japan followed from several recent scientific planning meetings on ocean lithosphere drilling, in particular the Mission Moho Workshop in 2006 (Christie et al., 2006; Ildefonse et al., 2007) and the "Melting, Magma, Fluids and Life" meeting in 2009 (Teagle et al., 2009). Those previous meetings reached a consensus that a deep hole through a complete section of fast-spread ocean crust is a renewed priority for the ocean lithosphere community. The scientific rationale for drilling a MoHole in fast-spread crust was developed in the workshop reports (available online) and most thoroughly articulated in the 2007 IODP Mission Moho drilling proposal (IODP Prop 719MP; www.missionmoho.org).

The 2010 MoHole workshop had two interconnected objectives, which have been discussed jointly between ocean lithosphere specialists, marine geophysicists, and engineers:

- to initiate a roadmap for technology development and the project implementation plan that are necessary to achieve the deep drilling objectives of the MoHole project,

- to identify potential MoHole sites in the Pacific (i.e., in fast-spread crust), where the scientific community will focus geophysical site survey efforts over the next few years.
Selecting drilling sites is essential to identify the range of water depths, drilling target depths, and temperatures that we anticipate, and to better define the technology required to be developed and implemented to drill, sample, and geophysically log the MoHole.

\section{A Brief Summary of the Scientific Rationale for the MoHole}

The Moho is the fundamental seismic boundary within the upper part of our planet, yet we have little knowledge of its geological meaning. New deep drilling technology now make it possible to fulfill scientists' long-term aspirations to drill completely through intact oceanic crust, through the seismically defined Moho and then a significant distance $(\sim 500 \mathrm{~m})$ into the upper mantle. Our scientific goals (Fig. 1; Christie et al., 2006; Ildefonse et al., 2007; Teagle et al., 2009) can be divided into the following principal tightly interconnected threads.

- What physical properties cause the Mohorovičić discontinuity, and what is the geological nature of this boundary zone?

- How is the (lower) oceanic crust formed at the mid-ocean ridges, and what processes influence its subsequent evolution? What are the geophysical signatures of these magmatic, tectonic, hydrothermal, biogeochemical, and chemical processes?

- What can we infer about the global composition of the oceanic crust, and what are the magnitudes of interactions with the oceans and biology and their influence on global chemical cycles?

- What are the limits of life, and the factors controlling these limits? How do the biological community compositions change with depth and the evolving physical and chemical environments through the oceanic crust?

- What is the physical and chemical nature of the uppermost mantle, and how does it relate to the overlying magmatic crust?

\section{The Mohorovičić Discontinuity}

In the oceans, the Moho is commonly a bright seismic reflector at $5-8 \mathrm{~km}$ depth, marking a step change to seismic 


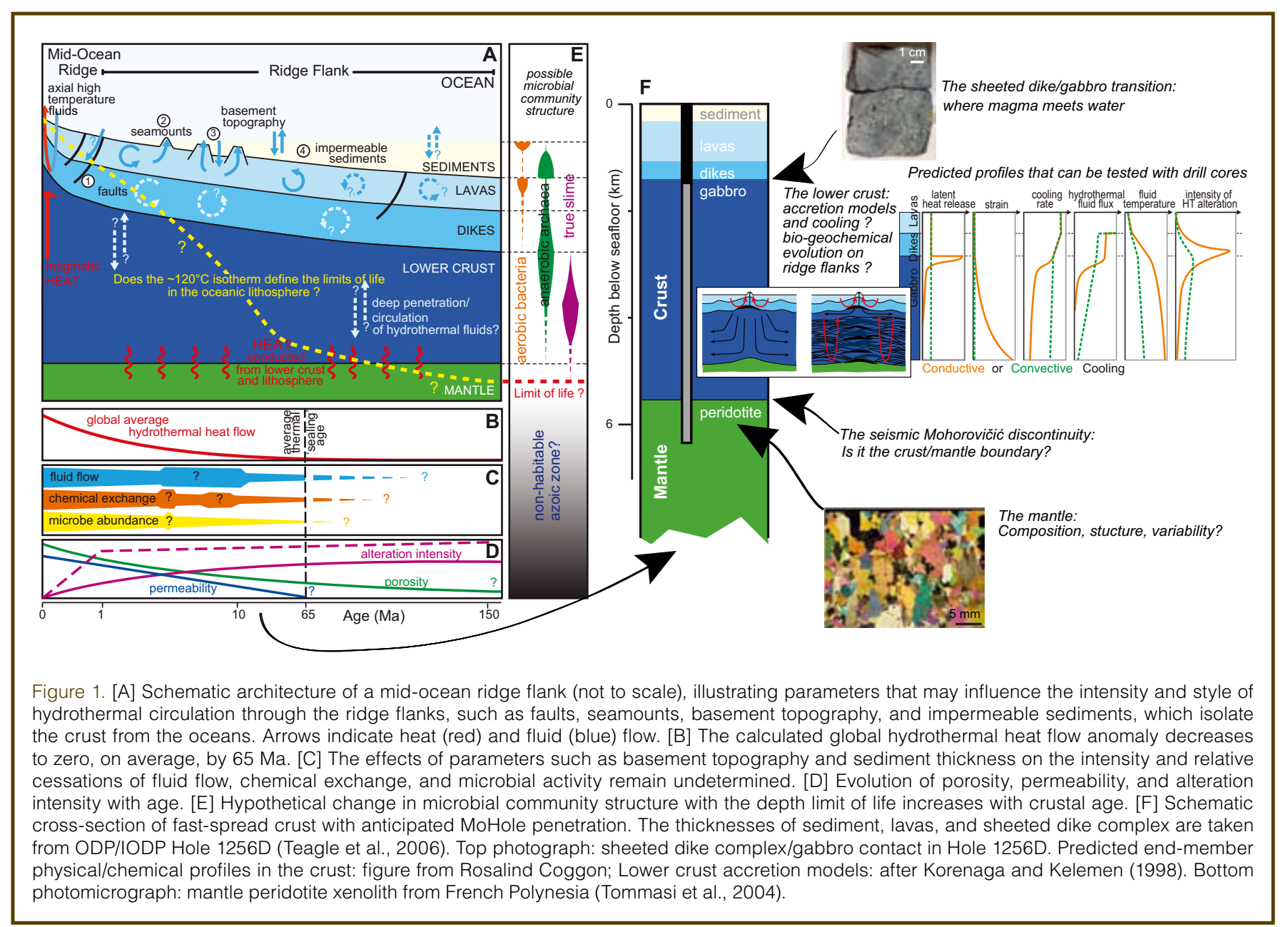

P-wave velocities ( $\mathrm{Vp}$ ) in excess of $8 \mathrm{~km} \mathrm{~s}^{-1}$. It is generally assumed that the Moho also represents the boundary between mafic igneous rocks (crystallized from magmas that form the crust) and residual peridotites of the upper mantle. However, this interpretation has never been tested, and there are geologically valid scenarios where the Moho might delineate the boundary between mafic and ultramafic cumulate rocks within the crust, or exist below serpentinized peridotites that were previously part of the mantle. Observations and sampling of the Moho, the petrological crust-mantle boundary, and the rocks of the upper mantle are fundamental to understanding the geodynamics and chemical differentiation of our planet. A foremost goal is to reconcile geophysical imaging of the Moho with direct geological observations of cores and downhole measurements (e.g., is the Moho in our study region a sharp compositional boundary or a transition zone of significant thickness?).

\section{Formation of the Lower Crust}

On the road to the Moho, we will make paradigm-testing observations of the lower oceanic crust and the deep magmatic, tectonic, and hydrothermal processes that occur at the mid-ocean ridges (Fig. 1). Our principal target will be intact ocean crust formed at a fast-spreading ridge, which should be relatively laterally uniform, and where we have well-developed theoretical models of crustal accretion that can be tested by drilling. Is the lower oceanic crust formed from the subsidence of a high-level magma chamber, or are there multiple melt bodies at different levels within the oceanic crust (or upper mantle) at fast-spreading ridges?

Magnetic stripes document the history of ocean crust formation and are the very basis of plate tectonic theory, yet we have little information on what contribution the lower crust has to this fundamental signature. Similarly, seismic profiling remains the key tool for investigating the deep crust, but these regional scale measurements have never been calibrated against core or in situ measurements. It remains challenging to confidently develop geological interpretations from geophysical measurement of the oceanic crust.

\section{Composition and Hydration of the Ocean Crust}

A full penetration will provide the first direct estimate of the bulk composition of ocean crust critical for Earth differentiation models. How deeply do seawater-derived hydrothermal fluids penetrate, and how efficient is hydrothermal circulation at heat extraction and chemical alteration (Fig. 1)? Is fluid flow channeled by major faults, or is it more perva- 
sive? The knowledge of modes of penetration of the hydrothermal fluids, and of the extent of their interactions with the lithosphere, is required to estimate chemical exchanges with the oceans, as well as to assess the volume and composition of materials transferred to the mantle via subduction.

\section{Limits and Controlling Factors of Life}

Understanding the limits of life (Fig. 1), and the factors controlling these limits, is one of the most fundamental goals of geo- and biosciences essential for understanding the origin, evolution, distribution, and future of life on Earth as well as celestial bodies. To date, the limits of life even on our own planet remain poorly defined. The MoHole project provides a unique opportunity to address these limits in the oceanic lithosphere that covers $\sim 60 \%$ of our planet. Numerous factors may control the limits of life, such as temperature, water activity, salinity, $\mathrm{pH}$, and energy and carbon sources. Among these, temperature plays a key role, because organisms cannot survive beyond as yet a poorly known temperature threshold $\left(\sim 110-120^{\circ} \mathrm{C}\right.$ ?). The ability of seawater to penetrate into the deep crust or mantle and be available for microorganisms (e.g., minimum pore space) will also have a strong impact on the distribution of living organisms.

\section{Physical and Chemical Nature of the Upper Mantle}

Direct observations of the mantle will document how magmas are focused from a broad melting region to a narrow zone of crustal accretion beneath mid-ocean ridges. Measurements across the Moho will quantify the tectonic coupling between the crust and mantle. We presently have little knowledge of the composition and physical state of in situ convecting mantle at the ridge axis. A few kilograms of fresh residual peridotite from beneath intact oceanic crust would provide a wealth of new information comparable to the treasure trove obtained from the Apollo lunar samples.

\section{Geophysical Characteristics of the Mohole Project Area}

The criteria for best possible deep crustal penetration sites were reformulated during this workshop. The selected target would ideally meet all of the following scientific requirements:

a) Crust formed at fast-spreading rate $\left(>40 \mathrm{~mm} \mathrm{yr}^{-1}\right.$ half rate).

b) Simple tectonic setting with very low-relief seafloor and smooth basement relief; away from fracture zones, propagator pseudo-faults, relict overlapping spreading basins, seamounts, or other indicators of late-stage intraplate volcanism. Connection to the host plate active constructive and destructive boundaries would provide important scientific information. c) Crustal seismic velocity structure should not be anomalous relative to current understanding of "normal" fast-spread Pacific crust, indicative of layered structure.

d) A sharp, strong, single-reflection Moho imaged with Multi-Channel Seismic (MCS) techniques.

e) A strong wide-angle Moho reflection (PmP), as observed in seismic refraction data, with distinct and clearly identifiable sub-Moho refractions (Pn).

f) A clear upper mantle seismic anisotropy.

g) A crust formed at an original latitude greater than $\pm 15^{\circ}$.

h) A location with relatively high upper crustal seismic velocities indicative of massive volcanic formations to enable the initiation of a deep drill hole.

Satisfying requirements for points a-e is essential for success. More flexibility is allowed in meeting points $\mathrm{f}-\mathrm{h}$, which are highly desirable but not essential. Several technological constraints limit the range of potential sites:

- Technology for re-circulating drilling mud (riser or alternative; see next section) is currently untested at water depths greater than $3000 \mathrm{~m}$.

- Prior scientific ocean drilling experience is mostly limited to temperatures less than $200^{\circ} \mathrm{C}$. Temperatures higher than $\sim 250^{\circ} \mathrm{C}$ will may limit choices of drill bits and logging tools, may decrease core recovery, and may increase risk of hole failure, or require substantial re-design of drilling equipment. Based on plate cooling models, crust older than $15-20$ Ma should meet this requirement at Moho depths (Fig. 2).

- Thickness of the crustal section above Moho must be at least a few hundred meters less than the maximum penetration/logging/recovery depth of the drilling system to allow significant penetration in mantle peridotites.

- Target area should be in a region with good weather conditions at least eight months out of the year, with calm seas and gentle ocean bottom currents.

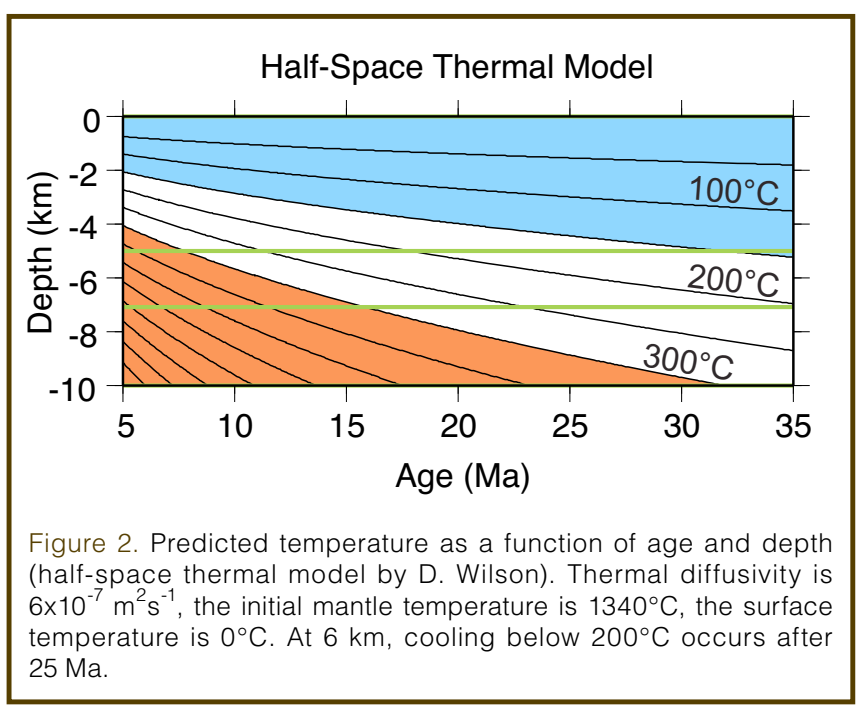


- Sediment thickness should be greater than $50 \mathrm{~m}$ to support possible riser hardware and other seafloor infrastructure (re-entry cones/uppermost casing strings).

- Targeted area should be close (less than $\sim 1000 \mathrm{~km}$ ) to major port facilities for logistical practicalities.

\section{Potential Sites}

Based on the scientific requirements and technological constraints described above, the workshop participants focused discussions on three areas in the Pacific Basin: Cocos Plate, off Southern and Baja California, and off Hawaii (Table 1; Fig. 3). One of the most important issues to take

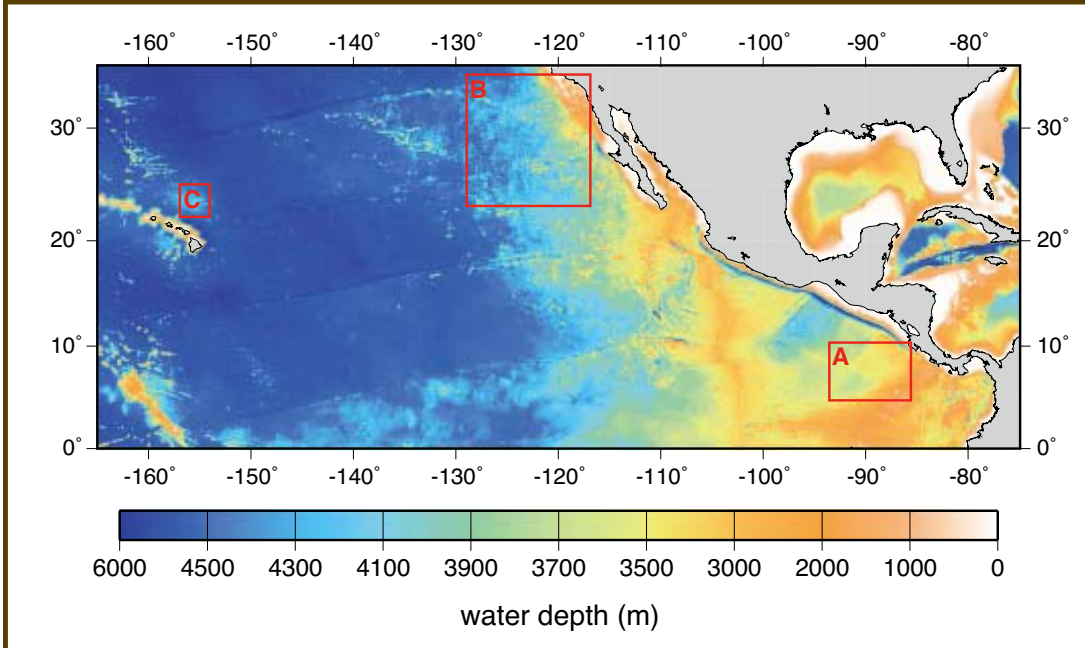

Figure 3. Bathymetric map showing the three selected areas for large-scale MoHole site survey: $[A]$ Cocos plate region, $[B]$ off Southern/Baja California region, [C] off Hawaii region. into consideration is the trade-off between seafloor depth and temperature at Moho depths. Most ocean seafloor subsides below $4000 \mathrm{~m}$ by $\sim 25 \mathrm{Ma}$, whereas at Moho depths of 5-7 km temperatures of $200^{\circ} \mathrm{C}$ or less are expected for crustal ages of 17-35 Ma (Fig. 2). The respective advantages and disadvantages of the three selected areas are listed in the full workshop report (available online at http://campanian.iodp.org/MoHole/).

The Cocos Plate region (Site 1256 area, Fig. 3A) encompasses a section of the Cocos Plate off Central America (from Guatemala to northern Costa Rica) with lithospheric ages between $15 \mathrm{Ma}$ and $25 \mathrm{Ma}$. At its western limit on 15-Ma crust, this area includes the Ocean Drilling Program (ODP) Hole 1256D (Wilson et al., 2006; Teagle et al., 2006), a site of ongoing Integrated Ocean Drilling Program (IODP) deep

drilling into intact ocean crust. MCS (Hallenborg et al., 2003; Wilson et al., 2003) and wide-angle ocean bottom seismometer (OBS) data exist for the 15-17 Ma area in the vicinity of Site 1256. This region sits in superfast crust (half-spreading rate $110 \mathrm{~m} \mathrm{yr}^{-1}$ ), within a corridor that includes a complete tectonic plate life cycle, making it an excellent candidate for understanding ocean crust evolution from a spreading center to subduction. Structure of the crust within this area can be directly related to processes occurring at the modern East Pacific Rise and the Central American subduction zone.

The off Southern/Baja California region (Fig. 3B) encompasses a section of the eastern Pacific Plate at $\sim 20^{\circ}-33^{\circ} \mathrm{N}$ and $\sim 130^{\circ}-118^{\circ} \mathrm{W}$. Crustal ages are $\sim 20-35$ Ma. Very little

Table 1. Principal characteristics of possible candidate sites for the MoHole project.

\begin{tabular}{|c|c|c|c|c|c|c|c|c|c|}
\hline 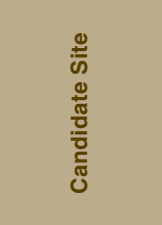 & 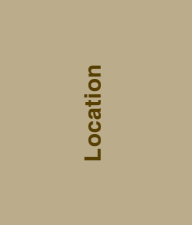 & 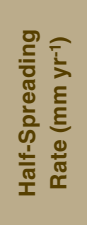 & 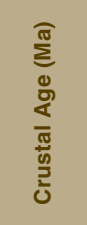 & 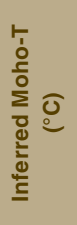 & $\begin{array}{l}\widehat{\Xi} \\
\text { है } \\
\frac{0}{0} \\
0 \\
\frac{0}{0} \\
\frac{\pi}{\pi}\end{array}$ & 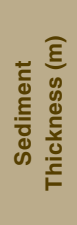 & 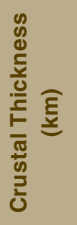 & 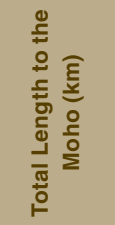 & 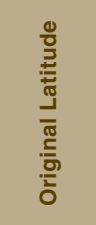 \\
\hline $\begin{array}{l}\text { Cocos } \\
\text { (Site 1256) }\end{array}$ & $\begin{array}{l}6.7^{\circ} \mathrm{N} \\
91.9^{\circ} \mathrm{W}\end{array}$ & 110 & 15 & $>250$ & 3646 & 250 & 5,5 & $8.7-9.2$ & $\begin{array}{l}\text { Near } \\
\text { equator }\end{array}$ \\
\hline $\begin{array}{l}\text { Cocos } \\
\text { (Site 844) }\end{array}$ & $\begin{array}{c}8^{\circ} \mathrm{N} \\
90.5^{\circ} \mathrm{W}\end{array}$ & 100 & 17 & $>250$ & 3414 & 290 & $5,5 ?$ & $8.7-9.2 ?$ & $\begin{array}{l}\text { Near } \\
\text { equator }\end{array}$ \\
\hline Cocos & $\begin{array}{l}8.7^{\circ} \mathrm{N} \\
89.5^{\circ} \mathrm{W}\end{array}$ & 100 & 19 & $\sim 250$ & $\sim 3400$ & 300 & $5,5 ?$ & $8.7-9.2 ?$ & $\begin{array}{l}\text { Near } \\
\text { equator }\end{array}$ \\
\hline $\begin{array}{l}\text { off S/Baja } \\
\text { California } \\
\text { (Deep Tow Site) }\end{array}$ & $\begin{array}{c}31^{\circ}-33^{\circ} \mathrm{N}, \\
125^{\circ}-127^{\circ} \mathrm{W}\end{array}$ & 60 & $30-27$ & $<200$ & $4300-4500$ & $\sim 100$ & $\sim 5.5 ?$ & $\sim 10 ?$ & $\sim 30-33$ \\
\hline $\begin{array}{l}\text { off S/Baja } \\
\text { California }\end{array}$ & $\begin{array}{c}28^{\circ}-29^{\circ} \mathrm{N} \\
123^{\circ}-125^{\circ} \mathrm{W}\end{array}$ & 50 & $27-22$ & 200 & $4200-4400$ & $\sim 100$ & $?$ & $?$ & $\sim 28$ \\
\hline $\begin{array}{l}\text { off S/Baja } \\
\text { California }\end{array}$ & $\begin{array}{c}25^{\circ}-26^{\circ} \mathrm{N} \\
120^{\circ}-122^{\circ} \mathrm{W}\end{array}$ & 60 & $27-22$ & $\sim 200$ & $3900-4300$ & $\sim 80$ & $?$ & $?$ & $\sim 30$ \\
\hline $\begin{array}{l}\text { off S/Baja } \\
\text { California }\end{array}$ & $\begin{array}{c}30.5^{\circ}-31^{\circ} \mathrm{N} \\
121^{\circ} \mathrm{W}\end{array}$ & 45 & $20-22$ & $\sim 250$ & $2700-4100$ & $\sim 130$ & $?$ & $?$ & $\sim 25$ \\
\hline Hawaii & $\begin{array}{c}22.9^{\circ}-23.7^{\circ} \mathrm{N} \\
154.9^{\circ}-155.8^{\circ} \mathrm{W}\end{array}$ & $35-40$ & $79-81$ & $\sim 150$ & $4050-4300$ & $\sim 200$ & $\sim 6 ?$ & $10-10.5 ?$ & $\begin{array}{l}\text { Near } \\
\text { equator }\end{array}$ \\
\hline Hawaii & $\begin{array}{c}23.5^{\circ}-23.9^{\circ} \mathrm{W} \\
154.5^{\circ}-154.8^{\circ} \mathrm{W}\end{array}$ & $35-40$ & 78 & $\sim 150$ & $4300-4500$ & $\sim 200$ & $\sim 6 ?$ & $10-10.5 ?$ & $\begin{array}{l}\text { Near } \\
\text { equator }\end{array}$ \\
\hline
\end{tabular}


modern geophysical information exists from this region. The best-studied area is in the northernmost part off San Diego, the "Deep Tow" site at $32^{\circ} 25^{\prime} \mathrm{N}, 125^{\circ} 45^{\prime} \mathrm{W}$ (31-32 Ma; Luyendyk, 1970). Historical data there include deep-tow sidescan and bathymetry, $3.5 \mathrm{kHz}$ profiler, magnetics, and single-channel seismics.

The off Hawaii region is located north of Oahu in the flexural arch, where water depths are $4000-4300 \mathrm{~m}$. The crust is $\sim 80 \mathrm{Ma}$ and was formed at an intermediate half-spreading rate of 35-40 $\mathrm{mm} \mathrm{yr}^{-1}$. This site offers the lowest temperature at Moho depth $\left(\sim 100^{\circ} \mathrm{C}-150^{\circ} \mathrm{C}\right)$, but crustal structure is potentially affected by hotspot volcanism (underplating and/or crustal intrusions), and its significantly older age makes it difficult to relate geochemical changes to modern ocean chemistry or conditions.

\section{Geophysical Surveys: Finding the Right Project Area}

The existing geophysical data at all potential sites are not sufficient to identify a clear MoHole Project target area. Consensus at the workshop was that the priority of the community should be directed toward conducting large-scale seismic surveys in the three selected regions, which will lead to the identification of a MoHole target that best satisfies the requirements stated above. These surveys should collect spatially coincident MCS data, wide-angle OBS data, multi-beam bathymetry and gravity. Heat flow and magnetic anomaly data will be useful and should be collected. The characteristics of the required seismic surveys are listed in the full workshop report. JAMSTEC will dedicate three months of science ship time in 2011 for large-scale surveys. There was a consensus that the first survey should be in the off Southern/Baja California region, because so little is known in this area (where depth/age/logistical criteria are viable). Baseline reconnaissance seismic data are urgently required to assess whether this area can possibly meet the scientific requirements. Two additional factors contributed to the choice of this region as short-term priority for initial reconnaissance: crustal ages are greater than near Site 1256 (so temperatures are expected to be cooler), and the existing data suggest that Moho in the Site 1256 area may not be associated with a simple, continuous, strong reflector.

After an appropriate drilling target has been identified, the community should conduct detailed seismic surveys in the vicinity of the specific target, including 3-D multi-streamer MCS and OBS surveys for accurate and geometrically correct imaging of intracrustal reflectors (faults, sills, etc.) and Moho, and to assess crustal structure and thickness variability, and upper mantle velocity structure/anisotropy.

The scope and costs of the surveys required for this project are too large to be undertaken by a single nation or funding agency, hence international collaboration is essential.

\section{Technology Development and Operations}

The MoHole initiative is arguably at the point where the framework for the operations can be constructed, since the technology to drill such a hole exists or at least has been shown to be feasible. The technology selection and required engineering development will be key components for the success of the MoHole project. It is important to identify potential issues in drilling and coring engineering from the past and ongoing ocean drilling expeditions, and to find solutions to overcome the problems encountered. The engineering efforts must be directed to ensure that the scientific goals of the MoHole project are achieved. Technology selection process and planning for the key engineering developments should be launched as soon as possible in conjunction with site-survey efforts. To do so, establishing a realistic roadmap, which includes project scoping, development and testing elements all controlled by proper project management, is imperative. All MoHole target sites are located in ultra-deep water of $\sim 4000$-m water depth or beyond, and the drilling depth to achieve the MoHole objectives is estimated to extend more than $6000 \mathrm{~m}$ below the seafloor. To drill such an ultra-deep borehole, the provision for continuous mud circulation is a top priority technology requirement. Other major areas requiring engineering consideration include logging and coring in high temperature environment, drill bits (specifically designed for abrasive, hard rocks) and drill string (high tensile strength), drilling mud (developed for high temperature environment), and casing/cementing materials and strategies (specifically designed, ideally to the bottom of the hole).

A promising candidate technology for drilling the MoHole is riser drilling, which provides a conduit for the mud to be returned to the vessel for cleaning, evaluation, and recirculation. The D/V Chikyu is currently equipped with a deep riser system with a maximum rated water depth of $2500 \mathrm{~m}$. Significant engineering development is required to prepare the D/V Chikyu for riser service in water depths $\geq 4000 \mathrm{~m}$. In addition to riser drilling, several other technologies are being considered to drill safely and efficiently to the target depth, including Surface Blow Out Preventer (BOP) with slim riser pipe (casing pipe) and Shut In Device (SID), or Riserless Mud Recovery (RMR; Myers, 2008) with mud circulation pump and mud return line. The lithologies intersected by the borehole drilled to Moho depths are unequivocally expected to be free from overpressures, hydrocarbons, or other geohazards. However, future regulatory changes may require the use of blow-out prevention in mud circulation systems. Hence, although a BOP will likely not be needed for well control, the use of a BOP will be considered by the MoHole planning group.

Drilling the MoHole will be a challenging enterprise requiring years of detailed preparation, planning, and engineering. Operationally, major challenges will be associated 
with collecting the cored material, making the in situ measurements, installing casing, and keeping the borehole open for successive episodes of deepening in a multiyear, multiphase operation. To gear up for the operations, all issues related to drilling, casing, coring, and logging must be adequately explored and included in a comprehensive and complete operation plan, as soon as the site characteristics are known. Key elements of the drilling/coring/downhole measurements were listed during the workshop (see full workshop report). The well design of the primary site may

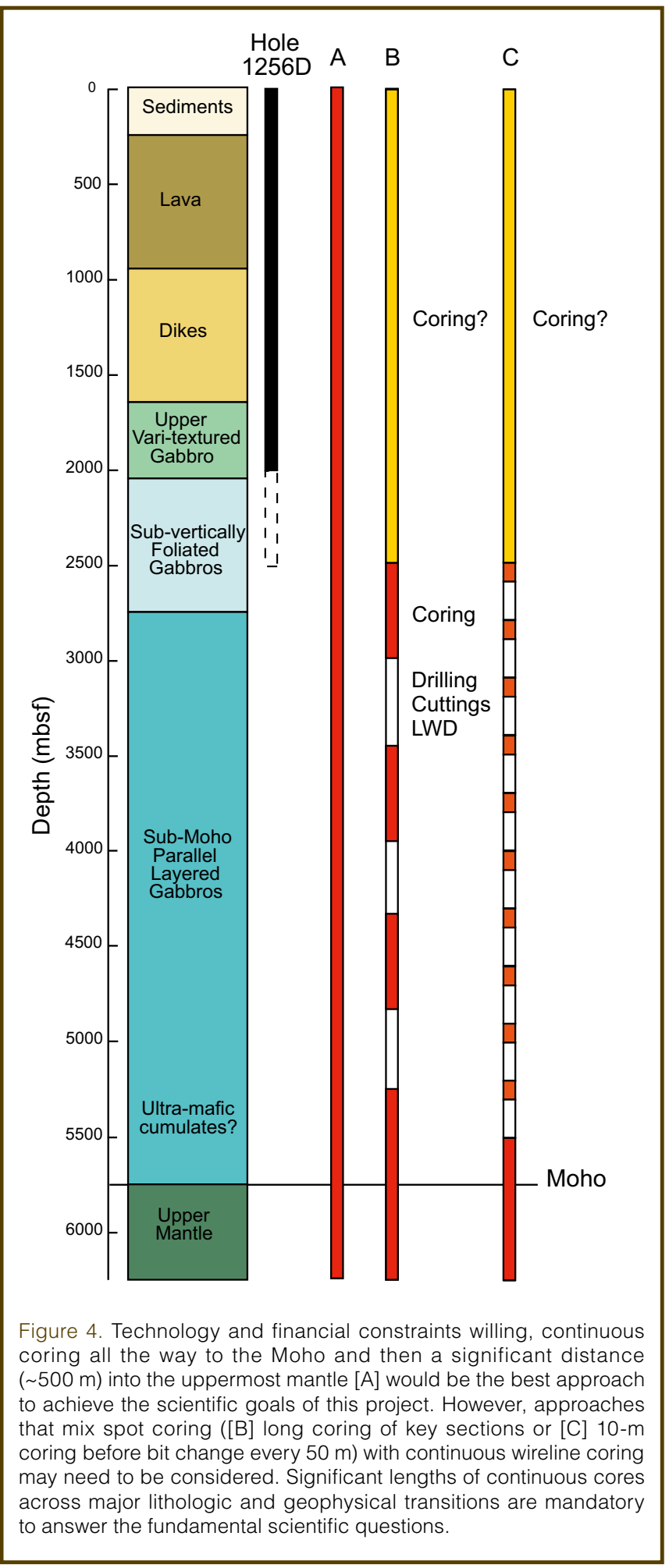

require data from a pilot hole, to properly evaluate parameters such as mud weights and casing set points. A pilot hole may be either a separate hole or simply a pilot section of the main hole. Drilling engineering data from a pilot section will be critical in managing the pressure, temperatures, and stress within the borehole.

After completion of drilling, coring, and borehole logging, the MoHole should be used for further experiments, including vertical seismic profiles (VSP), and long-term monitoring. Given the extreme borehole depth to be drilled, at least two offset VSPs are ideally required, one at the estimated halfway point of the well and perhaps one at final depth. Instrumenting the MoHole will eventually become a key, second-stage goal. Hence, the sub-sea equipment and borehole must be constructed to accommodate observatory science (e.g., fluid monitoring, microbiology incubation experiments). This implies ROV access to the wellhead and the ability to access the borehole through a BOP or SID.

\section{Keys for Success}

The keys for a successful MoHole project, as identified during the workshop, include scientific (essentially sampling strategy) considerations, as well as technology development, industry engagement, and public engagement through outreach activities and education. The MoHole project will be one of the largest scientific endeavors in Earth science history, and this challenge should provide precious opportunities to a diversity of scientists, engineers and technologists. One of the keys to success will be the sharing of the opportunities and achievements across a broad spectrum of Earth and life scientists.

The size and duration (ten years or more) of the MoHole project will require an appropriately supported, centralized science operations and engineering management group to oversee the successful initiation and completion of the project. This international group will be key to success and should be created as early as feasible. The envisioned, ideal timeline for the MoHole project is to complete prospective 2 -D site survey (including data analysis) in $\sim 2014$, choose the MoHole site and conduct 3-D site survey in $\sim 2015$, start preparing operations in $\sim 2015-2016$, start drilling in $\sim 2018$, and reach the mantle in $\sim 2022$.

\section{Scientific Coring, Sampling, and Measurements}

Many of our primary scientific goals will require continuous core samples. To be regarded as successful, the MoHole project must at least return the following (see also Fig. 4):

- Continuous core, including samples of all boundaries, across the region identified by seismic imaging as the Moho, and the lithologic transition from cumulate 
magmatic rocks to residual peridotites (these may or may not be the same target)

- Continuous coring of the lower $500 \mathrm{~m}$ of the mafic and ultramafic cumulate rocks in the oceanic crust

- Continuous coring of $500 \mathrm{~m}$ of peridotites and associated lithologies in the uppermost mantle below the Moho

- Sufficient cores from intervals of the lower oceanic crust to test models of crustal accretion and melt movement, to resolve the geometry and intensity of hydrothermal circulation, and to document the limits and activity of the deep microbial biosphere

- A continuous, comprehensive suite of geophysical logs (wireline, Logging While Drilling/Coring) and borehole experiments to measure in situ physical properties, to acquire borehole images, and to identify key geophysical and lithologic regions and transitions (e.g., Layer 2-3 boundary, the Moho) throughout the ocean crust and into the upper mantle.

Due to the expected relatively coarse grain size of the rocks to be encountered in the MoHole and the fine scales of expected lithologic/geochemical variation, it is anticipated that lithological records provided by mud/chip logging will be insufficient to address the scientific questions posed. However, a continuous series of mud, cuttings, and gas logs will provide useful supplementary information in areas of poor or no core recovery, and should be routine throughout the experiment. In addition to sampling and analyzing rocks, measurements of temperature and chemical compositions of fluids are required, together with biological analyses such as cell counting and DNA/RNA analyses.

\section{Drilling Technology and Industry Engagement}

Technologies that are applicable to the MoHole project are now being developed within the oil and gas industry. These were presented at the workshop by industry representatives. Conversely, some of the required technologies are very specific to scientific drilling, such as logging and coring at high temperatures (e.g., the IDDP project, Skinner et al., 2010) or drilling the hard crustal and mantle rocks. Development of such technologies will be a primary key for success, but to achieve this it may be necessary to complement IODP financial support with external funding.

As the oil and gas industry conducts operations in increasingly deep water, important keys for success will be continuous collaboration with industry and introduction of new technologies to the MoHole project where applicable. It will be necessary to establish a strategy to engage the industry in the project, exchange personnel, and plan joint development work. This can occur at several levels, including i) continuing ad hoc collaboration, through inviting oil and gas industry representatives to participate in planning activities and community workshops, ii) contracting services from planning to execution, and iii) participation of engineers and scientists engaged in the MoHole project to industry workshops, symposiums, and technology development forums.

\section{Public Engagement, Outreach, and Education}

Another key component of the success of a Mohole project will be to improve public support and understanding of the scientific goals and excitement of the project. Engaging the public through outreach and education activities, as well as being pro-active in advertising the project to the wider scientific community and engaging new groups of scientists, should be integral parts of the activities carried out by the MoHole project scoping group, under the umbrella of IODP and future international collaboration for scientific ocean drilling. One tool to be implemented rapidly, as soon as scoping activities commence, is a dedicated, dynamic and engaging MoHole web page.

\section{References}

Bascom, W.N., 1961. A Hole in the Bottom of the Sea: The Story of the Mohole Project. Garden City, New York (Doubleday and Company, Inc.): $352 \mathrm{pp}$.

Christie, D.M., Ildefonse, B., et al., 2006. Mission Moho - Formation and Evolution of Oceanic Lithosphere. Full workshop report. Portland, OR, U.S.A., 7-9 September 2006. Available online at http://www.iodp.org/mission-moho-workshop.

Hallenborg, E., Harding, A.J., Kent, G.M., and Wilson, D.S., 2003. Seismic structure of $15 \mathrm{Ma}$ oceanic crust formed at an ultrafast spreading East Pacific Rise: evidence for kilometerscale fracturing from dipping reflectors. J. Geophys. Res., 108(B11):2532, doi: 10.1029/2003JB002400.

Ildefonse, B., Christie, D.M., and Mission Moho Workshop Steering Committee, 2007. Mission Moho workshop: drilling through the oceanic crust to the mantle. Sci. Drill., 4:11-18. doi:10.2204/iodp.sd.4.02.2007.

Korenaga, J., and Kelemen, P.B., 1998. Melt migration through the oceanic lower crust: a constraint from melt percolation modeling with finite solid diffusion. Earth Planet. Sci. Lett., 156(1-2):1-11, doi:10.1016/S0012-821X(98)00004-1.

Luyendyk, B.P., 1970. Origin and history of abyssal hills in the northeast Pacific Ocean. GSA Bull., 81(8):2237-2260, doi:10.1130/0016-7606(1970)81[2237:OAHOAH]2.0.CO;2.

Myers, G., 2008. Ultra-deepwater riserless mud circulation with dual gradient drilling. Sci. Drill., 6:48-51. doi:10.22 04/iodp. sd.6.07.2008.

Shor, E.N., 1985. A chronology from Mohole to JOIDES. In Drake, E.T., and Jordan, W.M. (Eds.), Geologists and Ideas; A History of North American Geology. Geol. Soc. Am. Spec. Publ. 4. Boulder, CO (Geological Society of America): 391-399.

Skinner, A., Bowers, P., Pórhallsson, S., Friðleifsson, G.O., and Guðmundsson, H., 2010. Drilling and operating a core barrel for the Iceland Deep Drilling Project. GeoDrilling 
International, May 2010:18-21.

Teagle, D.A.H., Alt, J.C., Umino, S., Miyashita, S., Banerjee, N.R., Wilson, D.S., and the Expedition 309/312 Scientists, 2006. Proc. IODP, 309/312: Washington, DC (Integrated Ocean Drilling Program Management International, Inc.). doi:10.2204/iodp.proc.309312.2006

Teagle, D., Ildefonse, B., Blackman, D.K., Edwards, K., Bach, W., Abe, N., Coggon, R., and Dick, H., 2009. Melting, magma, fluids and life: challenges for the next generation of scientific ocean drilling into the oceanic lithosphere. Full workshop report. National Oceanography Centre, University of Southampton, 27-29 July 2009, available online at http:// www.interridge.org/WG/DeepEarthSampling/workshop 2009.

Tommasi, A., Godard, M., Coromina, G., Dautria, J.M., and Barsczus, H., 2004. Seismic anisotropy and compositionally induced velocity anomalies in the lithosphere above mantle plumes: a petrological and microstructural study of mantle xenoliths from French Polynesia. Earth Planet. Sci. Lett., 227:539-556. doi:10.1016/j.epsl.2004.09.019

Wilson, D.S., Hallenborg, E., Harding, A.J., and Kent, G.M., 2003. Data report: site survey results from cruise EW9903. In Wilson, D.S., Teagle, D.A.H., Acton, G.D., et al., Proc. ODP, Init. Repts., 206: College Station, TX (Ocean Drilling Program):1-49, doi:10.2973/odp.proc.ir.206.104.2003

Wilson, D.S., Teagle, D.A.H., Alt, J.C., Banerjee, N.R., Umino, S., Miyashita, S., Acton, G.D., Anma, R., Barr, S.R., Belghoul, A., Carlut, J., Christie, D.M., Coggon, R.M., Cooper, K.M., Cordier, C., Crispini, L., Durand, S.R., Einaudi, F., Galli, L., Gao, Y.J., Geldmacher, J., Gilbert, L.A., Hayman, N.W., Herrero-Bervera, E., Hirano, N., Holter, S., Ingle, S., Jiang, S.J., Kalberkamp, U., Kerneklian, M., Koepke, J., Laverne, C., Vasquez, H.L.L., Maclennan, J., Morgan, S., Neo, N., Nichols, H.J., Park, S.H., Reichow, M.K., Sakuyama, T., Sano, T., Sandwell, R., Scheibner, B., Smith-Duque, C.E., Swift, S.A., Tartarotti, P., Tikku, A.A., Tominaga, M., Veloso, E.A., Yamasaki, T., Yamazaki, S. and Ziegler, C., 2006. Drilling to gabbro in intact ocean crust. Science, 312(5776):1016-1020. doi: 10.1126/science.1126090.

\section{Authors}

Benoît Ildefonse, CNRS, Université Montpellier 2, CC60, 34095 Montpellier cedex 5, France, e-mail: benoit.ildefonse@ um2.fr.

Natsue Abe, Institute for Research on Earth Evolution (IFREE), Japan Agency for Marine-Earth Science and Technology (JAMSTEC), 2-15 Natsushima-cho, Yokosuka 237-0061, Japan.

Donna K. Blackman, Scripps Institution of Oceanography, UCSD, La Jolla, CA 92093-0225, U.S.A.

J. Pablo Canales, Woods Hole Oceanographic Institution, Department of Geology and Geophysics, Woods Hole, MA 02543, U.S.A.

Yoshio Isozaki, Marine Technology Center (MARITEC), JAMSTEC, 2-15 Natsushima-cho, Yokosuka 237-0061, Japan.
Shuichi Kodaira, Institute for Research on Earth Evolution (IFREE), Japan Agency for Marine-Earth Science and Technology (JAMSTEC), 3173-25 Showa-machi, Kanazawa-ku, Yokohama 236-0001, Japan.

Greg Myers, Consortium for Ocean Leadership, 1201 New York Avenue NW, Suite 400, Washington, DC 20005, U.S.A. Kentaro Nakamura, Precambrian Ecosystem Laboratory, JAMSTEC, 2-15 Natsushima-cho, Yokosuka 237-0061, Japan.

Mladen Nedimovic, Department of Earth Sciences, Dalhousie University, Edzell Castle Circle, Halifax, NS B3H 4J1, Canada.

Alexander C. Skinner, ACS Coring Services, 13 Riccarton Drive, Currie, Edingburgh, EH14 5PN, Scotland, U.K.

Nobukazu Seama, Research Center for Inland Seas, Kobe University, 1-1 Rokkodai, Nada, Kobe 657-8501, Japan

Eiichi Takazawa, Department of Geology, Faculty of Science, Niigata University, 2-8050, Niigata, 950-2181, Japan.

Damon A.H. Teagle, National Oceanography Centre, Southampton, University of Southampton, U.K.

Masako Tominaga, Department of Geology and Geophysics, Woods Hole Oceanographic Institution, Woods Hole, MA 02543, U.S.A.

Susumu Umino, Department of Earth Sciences, Kanazawa University, Kakuma-Machi, Kanazawa-Shi, Ishikawa 9201192, Japan.

Douglas S. Wilson, Department of Earth Science, UCSB, Santa Barbara, CA 93106-9630, U.S.A.

Masaoki Yamao, Center for Deep Earth Exploration (CDEX), JAMSTEC, 2-15 Natsushima-cho, Yokosuka 2370061, Japan.

\section{Related Web Link}

http://campanian.iodp.org/MoHole/ 